\title{
Evaluation of Sweet Potato (Ipomoea Batatas (L) Lam) Varieties at Tepi, Southwestern Ethiopia
}

\author{
Shamil Alo Sora* \\ Department of Horticulture, Ethiopian Institute of Agricultural Research (EIAR), Addis Ababa, Ethiopia. Tepi Agricultural Research Center, Tepi, Ethiopia
}

*Corresponding author: Shamil Alo Sora, Department of Horticulture, Ethiopian Institute of Agricultural Research (EIAR), Addis Ababa, Ethiopia. Tepi Agricultural Research Center, Po. Box 34, Tepi, Ethiopia.
Received Date: February 24, 2021

Published Date: March 31, 2021

\begin{abstract}
Sweet potato (Ipomoea batatas (L.) Lam.) is one of the globally important root crops. In Ethiopia, its production is confronted with lack of planting materials, shortage of farmer preferred varieties, poor extension system among many other constraints. The study was conducted to assess the performance of different released varieties at Teppi. Evaluation of the varieties was carried out in main cropping season. Each treatment was replicated three times and arranged in Randomized Complete Block Design. Stand count at harvest, number of roots per plant, plant height, total root yield, root length and root diameter were measured. All the traits showed significant difference between varieties. The highest root yield (50.83 $\mathrm{t} / \mathrm{ha})$, root length $(24.77 \mathrm{~cm})$ and root diameter $(10.35 \mathrm{~cm})$ were recorded for the variety Awassa-83. The lowest root yield $(27.67 \mathrm{t} / \mathrm{ha})$, root length $(8.9 \mathrm{~cm})$ and root diameter $(4.75 \mathrm{~cm})$ were recorded for the variety Cemsa, Beletech and Temesgen, respectively. The highest number of roots per plant (4.03) was recorded for the variety Cemsa and there was no significant difference observed between other varieties. The findings of the study revealed that, Awassa-83 was found to be more adapted to the area as compared to other varieties. This variety should be popularized and disseminated to users to boost the production and productivity of Sweet Potato in the area.
\end{abstract}

Keywords: Sweet potato; Yield

\section{Introduction}

Sweet potato (Ipomoea batatas (L.) Lam.) is an important food security crop for the millions of people in Africa. It is one of the globally important crops ranking seventh and fifth in production in the world and in Africa, respectively [1]. Sweet potato served as emergency relief crop in the country at the time of either natural or manmade disasters. It is entirely usable crop: roots for human consumption and roots and tops for animal feed, it is planted by many farmers of SNNPRS and Oromia as choice crop to alleviate food and feed shortage [2]. It is an autopolyploid $(2 n=6 x=90)$ crop with a basic chromosome number of 15 [3]. It produces storage roots which are rich in carbohydrate, vitamins such as A, B complex, $\mathrm{C}, \mathrm{E}$ and minerals such as potassium, calcium and iron. Root crops like Potatoes, Sweet Potatoes and Taro are among the list of major food crops that are consumed across the country. These and other economic importance prompt the peasant holders to grow many of the root crops as shown in the survey results [4]. In 2017/18 cropping season, the total area under production is estimated to be 53449.23 hectares and the production is estimated to be 1848413.74 tons with the productivity of 34.58 tons per hectare [4].

The current yield of sweet potato in developing countries is very low, nearly 3-6 tons ha-1, while the potential yield is reported to be in the range of 40-50 tons ha-1 [5]. In Ethiopia, sweet potato is widely grown in south, southwestern and eastern parts by small-scale farmers with limited land, labor and capital. Ethiopia is one of the largest sweet potato producing countries in the world. 
According to the Central Statistical Authority [4] reports, sweet potato occupied about 53,499 hectares of land with a total annual production of 1.85 million tons during the main growing season only. However, the average national productivity of the crop as compared to the potential yield of the varieties. According to [2], the trends of sweet potato production in Ethiopia over the last 14 years (2005-2018) shows that the production and productivity of the crops has been increasing, especially as of 2012, both at national level as well as at the largest producing region (SNNPR). However, the frequent drought in production ecologies, incidence of sweet potato viral disease, lack of market and alternate utilization possibilities have greatly hindered the expansion of the production of this crop in Ethiopia [2]. Among the major biotic constraints for sweet potato production insect pests are recoded as the major one [2]. Limitation in the genetic improvement of the crop due to Polyploidy and the large chromosome number, coupled with selfand cross-incompatibilities among different genotypes could also be mentioned as one of the constraints. In addition, the flowering prolificacy in sweet potato is variety dependent, where some varieties may not flower at all and others produce very few flowers. Self- and cross incompatibilities provide a major challenge to sexual recombination, seed production and genetic improvement in sweet potato [6].

Low root dry matter content in the orange fleshed Sweet Potato varieties and a lack of knowledge on postharvest storage and processing are also some of the prevailing constraints of the crop [1]. The absence of any formal institutions that multiply and supply quality planting materials for users also mentioned as limiting factors to disseminate the available technologies [1].
To overcome the above-mentioned problems, providing improved varieties which out yield the local variety is of paramount importance to increase accessibility of balanced food and household income. To advance improvement of crop productivity in different localities, continual identification of the best and suitable crop technologies appeared to be essential. This can be achieved, through adaptability tests and generation of new technologies. Keeping this in view, the present study was conducted at Tepi Agricultural Research Center to test the performance of released Sweet Potato varieties for their adaptability in Tepi area.

\section{Materials and Methods}

\section{Description of the study area}

The experiment was conducted at Tepi during 2016 cropping season at Tepi Agricultural Research Centre. Tepi located in south western Ethiopia in Southern Nations Nationalities and Peoples (SNNP) Regional State at an elevation of 1200 meter above sea level and it is situated at Latitude of $7^{\circ} 10,54.5$, and with a Longitude of $35^{\circ} 25,04.3-28.2$, E of Ethiopia. The research station receives an annual average rainfall of $1559 \mathrm{~mm}$ with maximum and minimum temperatures of $29.7^{\circ} \mathrm{C}$ and $15.5^{\circ} \mathrm{C}$, respectively. The soil of experimental site is reddish brown sandy clay loam classified as nitosol with PH range of 5.6 to 6.0.

\section{Treatments and experimental design}

The treatments consist of 6 white fleshed improved varieties of sweet potatoes. The treatments were arranged in a Randomized Complete Block Design (RCBD) with three replications, making a total of 18 experimental plots (Table 1).

Table 1: List and description of released Sweet Potato varieties used for the experiment.

\begin{tabular}{|c|c|c|c|c|c|c|c|}
\hline No. & Variety & Year of Release & Altitude & Maturity Days & Flesh Colour & Yield (t/ha) & Center of Release \\
\hline 1 & Awassa-83 & 1983 & $1200-2200$ & $150-180$ & White & 36.6 & Hawasa \\
\hline 2 & Koka-6 & 1987 & $1200-2200$ & $120-150$ & Cream & 26.9 & Hawasa \\
\hline 3 & Temesgen & 2002 & $1200-2200$ & $90-120$ & White & 17.6 & Hawasa \\
\hline 4 & Berkume & 2007 & $1650-2000$ & $188-195$ & White & 19.5 & Haromaya Univ. \\
\hline 5 & Beletech & 2004 & $1200-2200$ & 150 & White & 18.4 & Hawassa \\
\hline
\end{tabular}

Source: Ministry of Agriculture Crop variety registration bulletin (1983-2017).

Table 2: Mean performance of Sweet Potato varieties at Teppi.

\begin{tabular}{|c|c|c|c|c|c|c|}
\hline Varieties & Vine Length (cm) & Stem Girth (cm) & Number of Roots per Plant & $\begin{array}{c}\text { Root } \\
\text { Length(cm) }\end{array}$ & $\begin{array}{c}\text { Root Diame- } \\
\text { ter(cm) }\end{array}$ & $\begin{array}{c}\text { Total Yield (Tone } \\
\text { per Hectare) }\end{array}$ \\
\hline Koka-6 & $175.07^{\mathrm{a}}$ & $0.63^{\mathrm{a}}$ & $2.23^{\mathrm{b}}$ & $19.97^{\mathrm{b}}$ & $6.77^{\mathrm{bc}}$ & $37.13^{\mathrm{b}}$ \\
\hline Awassa -83 & $171.07^{\mathrm{ab}}$ & $0.64^{\mathrm{a}}$ & $2.77^{\mathrm{b}}$ & $24.77^{\mathrm{a}}$ & $10.35^{\mathrm{a}}$ & $50.83^{\mathrm{a}}$ \\
\hline Berkume & $162.6^{\mathrm{abc}}$ & $0.71^{\mathrm{a}}$ & $2.63^{\mathrm{b}}$ & $20.13^{\mathrm{b}}$ & $7.79^{\mathrm{b}}$ & $30 \mathrm{c}$ \\
\hline Cemsa & $160.6^{\mathrm{abc}}$ & $0.47^{\mathrm{b}}$ & $4.03^{\mathrm{a}}$ & $19.17^{\mathrm{bc}}$ & $5.56^{\mathrm{bc}}$ & $27.67^{\mathrm{e}}$ \\
\hline Beletech & $138.67^{\mathrm{bc}}$ & $0.43^{\mathrm{b}}$ & $2.43^{\mathrm{b}}$ & $8.9^{\mathrm{d}}$ & $4.99^{\mathrm{c}}$ & $29 \mathrm{~d}$ \\
\hline Temesgen & $135.2^{\mathrm{c}}$ & $0.47^{\mathrm{b}}$ & $2.3^{\mathrm{b}}$ & $16.3^{\mathrm{c}}$ & $4.7^{5} \mathrm{C}$ & $28.03^{\mathrm{e}}$ \\
\hline LSD (5\%) & 33.36 & 0.13 & 1.26 & 3.091 & 2.42 & 2.91 \\
\hline CV (\%) & 11.67 & 12.7 & 25.34 & 9.33 & 2.88 & 1.49 \\
\hline
\end{tabular}




\section{Experimental procedures and field management}

The experimental land was well prepared, and ridges were prepared manually with hand hoes. The plot size for each variety was $9 \mathrm{~m}^{2}(3 \mathrm{~m} \times 3 \mathrm{~m})$ and the spacing of $0.6 \mathrm{~m}$ and $0.3 \mathrm{~m}$ between ridges and plant were used respectively. The experiment was done at Teppi agricultural research center. Uniform Sweet Potato vine cuttings of $30 \mathrm{~cm}$ length were taken and planted at the onset of rainy season in the experimental plot by burying two thirds of their lengths into the soil at $45^{\circ}$ angles. One vine cutting was planted in each hole of the ridge. Earthing-up was done to protect the exposure of the storage roots. All agronomic practices were applied uniformly to all treatments according to the recommendation for the crop.

\section{Results and Discussion}

The result showed that there was significance difference between the varieties at $\mathrm{p}<0.05$. The highest plant height was recorded for Koka-6 and Awassa 83 (175.07) and (171.07) cm respectively. The shortest plant height was recorded by Beletech and Temesgen (138.67 and $135.2 \mathrm{~cm}$ ) respectively (Table 2). Berhanu \& Beniam [7] also reported that, vine length was significantly affected by the interaction effects of site and variety. The result showed that there was significance difference between the varieties at $p<0.05$. The highest Stem girth was recorded at Berkume, Awassa-83 and Koka- $6(0.71,0.64$ and $0.63 \mathrm{~cm})$ respectively. The lowest Stem girth was recorded by Beletech $(0.43 \mathrm{~cm})$ respectively (Table 2). From analysis of variance, all varieties showed significant difference in both years but Cemsa recorded the highest number of roots per plant 4.03 (Table 2). The lowest number of roots per plant was recorded from Koka-6 (2.23). This weight difference may be come from genetic capability of the sweet potato varieties [8]. From the analysis, it was revealed that root length was highly significant at $\mathrm{p}<0.01$.

The highest root length per plant was recorded by Awassa-83 (24.77) sweet potato varieties and the lowest length was recorded by Beletech (8.9) (Table 2). The result showed that there was significance difference between the varieties at $p<0.05$. The highest Root diameter was recorded at Awassa-83 (10.35cm). The lowest Root diameter was recorded by Temesgen (4.75) (Table 2). Berhanu \& Beniam [7] also reported that root diameter was high significantly affected by variety. From the analysis of the result, there were high significance difference between the varieties at $\mathrm{P}<0.01$. The highest root yield (50.83.ton ha-1) was recorded for variety Awassa 83. In contrast, the lowest root yield (27.67 -ton ha-1) was recorded for varieties Cemsa (Table 2). The result showed that sweet potato yield varied among varieties. The variation in yield among varieties may be attributed to weather or climatic factors, and the duration of growing periods. Nair (2000) also reported that sweet potato yield varies with the variety, season of planting, soil condition and fertility. Osiru et al. [5] also reported that sweet potato yield varied among genotypes.

\section{Summary and Conclusion}

Root and tuber crops play significant role in contribution towards food security, income generation, provision of food energy and resource base conservation. Six released sweet potato varieties were tasted at Tepi Agricultural Research Center in randomized complete block design with three replications. The experiment was carried out to test the performance of improved sweet potato varieties and identify and select the best high yielding, pest and disease resistant/tolerant variety/ies for the target area. The mean root yield was ranged from 27.67 to $50.83 \mathrm{t} / \mathrm{ha}$, for Cemsa and Awassa-83 respectively. The mean root length and mean root diameter was ranged from $16.3 \mathrm{~cm}$ to 24.77 and 4.747 to $10.35 \mathrm{~cm}$ for Temesgen and Awassa-83 respectively. Based on mean yield, Awassa-83 and Koka- 6 gave highest yield [9]. All varieties showed significant difference for most of the studied traits. The highest yield was obtained by Awassa-83 and the least yield was recorded by Temesgen and Cemsa. In general, Awassa- 83 and Koka- 6 showed better adaptation as compared to other varieties and have to be multiplied and disseminated to users. Further study should be carried out with improved varieties to improve potato production, especially in Southwestern parts of Ethiopia.

Sweet potato is one of the most important root and tuber crop for food and feed value. It is recognized as ideal crop for food security. Sweet Potato has high potential for improving food security, increasing household income and poverty reduction. Despite these; a set of constraints along the sweet potato production has to be considered simultaneously, to ensure higher yields, better income, and a significant contribution of Sweet potato farming to food security, nutritional security and improved livelihoods in the country. The best adapted varieties like Awassa-83 should have to be multiplied and disseminated to the area. Sweet Potato varieties that have high yielding, good resistance to Sweet Potato virus and tolerant to different biotic and abiotic factors as well as varieties with high nutritional qualities have to be released and disseminated to boost Sweet Potato production and productivity $[10,11]$.

\section{Acknowledgement}

My special thanks go to Ethiopian Institute of Agricultural Research and Teppi Agricultural Research Centre for financial support. The contributions of individuals, who involved directly and indirectly in field follow up and data collection, are well acknowledged.

\section{Conflict of Interest}

No conflict of interest. 


\section{References}

1. Fekadu G, Shimelis H, Mark L (2015a) Diagnostic assessment of sweet potato production in Ethiopia: constraints, post-harvest handling and farmers' preferences. Research on Crops 16(1): 104-115.

2. Gurmu F (2019) Sweetpotato Research and Development in Ethiopia: A Comprehensive Review. Journal of Agricultural and Crop Research 7(7): 106-118.

3. Lebot V (2010) Sweet potato. In Root and tuber crops. Springer, New York, NY, pp. 97-125.

4. CSA (2018) Ethiopia Agricultural Sample Survey 2017/2018: Report on Land Utilization (Private Peasant Holdings, Meher Season). Central Statistical Agency (CSA), Federal Democratic Republic of Ethiopia, Addis Ababa, Ethiopia.

5. Osiru MO, Olanya OM, Adipala E, Kapinga R, Lemaga B (2009) Yield stability analysis of Ipomoea batatus L. cultivars in diverse environments. Australian Journal of Crop Science 3(4): 213-220.

6. Vimala B, Hariprakash B (2011) Variability of morphological characters and dry matter content in the hybrid progenies of sweet potato (Ipomoea batatas (L) Lam). Gene conserve 10(39).
7. Berhanu T, Beniam T (2013) Performance Evaluation of Improved Sweet Potato (Ipomoea batatas L.) Varieties at Gedeo Zone, Southern Ethiopia. International Journal of Science and Research (IJSR) 6(14): 2319-7064.

8. Nedunchezhiyan M, Byju G, Jata SK (2012) Sweet potato agronomy. Fruit, Vegetable and Cereal Science and Biotechnology 6(1): 1-10.

9. Nair GM (2000) Cultural and manurial requirements of sweet potato. Production Technology of Tuber Crops, Central Tuber Crops Research Institute, Thiruvananthapuram, Kerala, India, pp. 44-64.

10. Ferdu A, Baye M, Emana G, Temesgen A, Eyobe T, et al. (2009) Review of Entomolological Research on Root and Tuber Crops in Ethiopia. In: Abraham Tadesse(ed.). (2009) Increasing Crop Production through Improved Plant Protection- Vilume II. Plant Protection Society of Ethiopia (PPSE). PPSE and EIAR, Addis Ababa, Ethiopia, Pp. 1- 46.

11. Fekadu G, Shimelis H, Mark L (2013) Self- and Cross incompatibilities in Sweet potato and Their Implications on breeding. Aus J Crop Sci 7(13): 2074-2078. 